\title{
AN EFFECTIVE MOOC MODEL TO SUPPORT FREEDOM TO LEARN PROGRAM
}

\author{
Ahmad Chafid Alwi ${ }^{1}$, Siti Irene Astuti Dwiningrum ${ }^{2}$, Suyanto ${ }^{1}$, Sunaryo Sunarto ${ }^{3}$, \\ and Surono ${ }^{3}$ \\ ${ }^{1}$ Faculty of Economics, Universitas Negeri Yogyakarta, Indonesia \\ ${ }^{2}$ Faculty of Education, Universitas Negeri Yogyakarta, Indonesia \\ ${ }^{3}$ Faculty of Engineering, Universitas Negeri Yogyakarta, Indonesia \\ email: ahmadchafidalwi@uny.ac.id
}

\begin{abstract}
This study was aimed at exploring an effective and proper MOOC model which is in line with the learning need of Indonesian society, especially in pandemic era. This study was conducted by employing Content Analysis in IndonesiaX and sekolahpintar.com platforms. The data obtained were analysed by identifying the differences and the similarities of each MOOC. The results show that a good MOOC model such as IndonesiaX has a more structured presentation of content, videos with fresh visuals and excellent evaluation. The questions presented also not only measure low order thinking skills, but also present high order thinking skills questions that are not available at SekolahPintar.com. An effective MOOC model must meet the CDT (Component Display Theory) and dimensions of effective online learning, be able to motivate students to learn independently and be able to create student involvement in collaborative discussions. The motivation is more effective if it is continuously aroused by delivering proper strategies, which is in line with the need.
\end{abstract}

Keywords: effective MOOC model, freedom to learn program, content analysis

\section{INTRODUCTION}

National calamity caused by Covid-19 Pandemic has paralyzed all aspects of life including education, economic and social aspect. In Indonesia, there has been increasing number of those infected by Covid-19 up to $1600-4000$ patients per day. It results in increasing number of unemployment due to massive lay off for 3.05 millions of workers. In addition, it is possible that recession will occur just like what happened in other countries (CNNIndonesia.com, 2020; Tempo, 2020). Covid-19 Pandemic has also created crisis to all aspects of life and in Indonesia, the most severe crisis occurs on education and economic sector. Economic and educational activities are greatly limited. Therefore, government has launched new policy for education in the form of distant education program starting from elementary to higher education. It encourages both formal and informal educational institution to set up distant education program.

Covid-19 Pandemic creates massive change on instruction at school. Circular letter of Education and Culture Minister of Indonesia no 4 of 2020 states that Distant Education Program or Study From Home program is conducted to give meaningful learning experience on the part of students leaving aside the burdenn of mastering all contents of curriculum which focus on life skill education. Instructional activities and task might be given qualitative or quantitative feedback. Instructional process might be delivered in the form of online, semi online or offline instruction. Then, it is found out that its impact is more accelerative which is shown by various change occurred. 
Parents who used to work in formal sector start to work at home. Some of them are laid off which mostly influenced informal workers due to economic downturn. Distant education program requires active part of parents to monitor their children learning. This is of course hard to deal with and there should be solution for that.

In facing pandemic era, there is a need of instructional facilities which are not only able to facilitate parents in mentoring their children but also to enhance people's skill during working at home. One of the facilities that might be used is learning website providing open access for everyone. Limited access for classroom instruction and offline training has driven the need for distant learning. Despite the MOOC preceding overview (Chauhan \& Goel, 2017; Onah et al., 2014) which denoted some issues pertaining this platforms, it is highly flexible and able to arouse learning independency and active motivation for learning (Firman \& Rahayu, 2020). Contra argument about that negativity, has also been refuted by Conijn $e t$ al. (2018) by stating that the final result of the text completion is significant after underwent some treatment along with its criterion. It seems that distant learning during pandemic is the best alternative to learn and to maintain students' health. Government has also conducted numerous efforts to give more access to distant learning.

Alternative learning method should be designed in such a way that it can be delivered effectively. However regarding its implementation, adapting process of instruction during pandemic has not been adaptive and proactive. Numerous instructional problems have come up during distant learning such as low mastery level of technology, inadequate number of means and infrastructure for distant learning, limited internet access, and complicated relocation of national budget for education (Aji, 2020).
Therefore, learning from home program has not been effectively conducted (Gamage et al., 2015; Reich, 2015). There has been complaint on the function of parents as teachers because not all parents have undergone teacher training program or have teaching experience. It triggers conflict between parent and students. Due to all afore-mentioned problems, people comes to realize on the importance of distant education program after the onset of Covid-19 Pandemic. In addition, it has not been easy for either students or parents to adapt themselves with online independent study habit. Low level of independent learning habit is shown by the study finding conducted by (Kusmawan, 2016) using 279 respondent of Universitas Terbuka who teachers of elementary students in various area of Indonesia. The study shows that level of independent learning habit of students of Universitas Terbuka is on 'moderate' category.

The word 'Massive' in MOOC means strong, reliable and firm; the word online is closest in meaning to access by using internet network and course is similar to training. Therefore, MOOC might be defined as open online training for everyone by using reliable and firm system. MOOC model has been developed since 2015. It is considered as future instructional system. The onset of pandemic forces us to adapt ourselves to distant education program. There are two types of MOOC namely MOOCs and MOOCx. The difference between the two is on their access limitation. MOOCx requires financial compensation and MOOCs is free to access. Actually, MOOC is not something new in education. It has been widely known as Massive Open Online Course Education (abbreviated as MOOC) and it plays more crucial role in pandemic times than before. Before pandemic, MOOC only functions as supporting means for Blended Learning which integrates online and offline 
instruction. At university level, MOOC are employed by those joining distant education program such as that owned by Gajah mada University, Binus University, Universitas Terbuka and several others.

The development of MOOC shows that it is widely used by many countries by using different specification strategy. MOOC was firstly introduced by Dave Cormier, manager of Web Communication and Innovations at University of Prince Edward Island and his colleague, Bryan Alexander, senior researcher at National Institute for Technology in Lineral Education at an open course program held by George Siemens (Associate Director, Technology Enhanced Knowledge Research Center in Athabasca University) and Stephen Downes (Senior Researcher at The National Research Council, Canada). At that time, they set up a course entitled "Connectivism and Connective Knowledge" followed by 25 students of Extended Education at University of Manitoba and 2300 students of general people taking free online course (Purnomo, 2016).

MOOC plays more significant role during Covid-19 Pandemic. At University of Manitoba, MOOC has shown to be effective means of instruction during pandemic. In Indonesia, it is expected that MOOC might be alternative free and easy to use learning resources for teachers, students and general people. Therefore, it is expected that MOOC is able to support government of Indonesia to develop education of Indonesian People. In addition, MOOC also supports Freedom to Learn Program requiring strategic and varied instructional process.

For Freedom to Learn program, MOOC facilitates all people to get know-ledge because it can be accessed from anywhere. People are free to choose types of knowledge they want to get, to get the best instructor and others. To explore the dynamics of MOOC, this article elaborates an effective model of MOOC to support Freedom to Learn program. In addition to, it also tries to find out aspects that have not been met in MOOC in Indonesia.

Lock Down policy in Indonesia enacted since March 2020 requires workers to work from home. This, of course is new. It is hard for those working in private companies and government institution who are usually work under supervision from their superior.

Conflict due to the implementation of work from Home (WFH) program occurs due to different mindset on the part of our people. Pandemic changes our mind set on home as place to rest and live into place to work or study. Several studies show several drawbacks of WFH such as lack of team work and inadequate monitoring (van der Lippe \& Lippényi). However other studies shows that WFH is able to provide flexibility, and discretion for have their job done without being monitored by their superior (Kossek et al., 2015).

MOOC is a platform developed for instruction. In line with its name, this platform is "open" meaning that it can be accessed by everyone from everywhere. It contains various modes of learning material such as text, slides, presentation, recordings and mashup (video with slides). It has simple interface to facilitate users and assessment features for learning development. Users may have discussion with instructors in provided forum and read feedbacks on task submitted. Even, several MOOC provides badges for their best students.

MOOC is an e-learning platform however not all e-learning platforms are MOOC. There are several differentiating features between MOOC and e-learning (non-MOOC). According to openmooc. org, MOOC features are of solutions for joining free courses which are $100 \%$ open for everyone; materials are presented by using various modes such as text, presentation 
slides, recordings, video and mashup; simple interface that is easy to browse; it has assessment feature of learning progress; it has discussion forum between students, students-instructors, and tutor-providers; it has feedback features; it is not necessary to use local streaming video service; it has "what you see is what you get" interface; it has badge for good behaviour in forum; and it is identified by Federation of Security Assertain Markup Language (SAML2).

MOOC is an instructional platform. It is designed based on independent learning theory. According to Laird (Mudjiman, 2011 pp. 14-16), independent learning is characterized by self-directing learning activities, self-replied questions coming up during learning process based on existing experience, being not dictated by teachers, a condition in which adolescents expect immediate appreciation from what they have learned, problem-based condition, a condition where active participation is more attractive, condition in which students are able to make use their experience, collaborative instruction is more attractive, being able to plan their own instruction, and condition in which learning means doing something and not only absorbing information. As one of the distant learning modes, there are several principle of MOOC that should be taken into account by its developer. MOOC may be accessed by using computer, laptop or smartphone. Therefore, Component Display Theory (CDT) is appropriate for adopting principles of MOOC. There are several other factors that must be taken into account namely learning theories, presentation strategies, learning principles, principle of resource-sharing, model used and local culture.

Instructional design theories have three components which are descriptive theory on knowledge to be taught to and skills to be obtained by students, descriptive theory on instructional strategies that will direct students to achieve their instructional objectives, perspective theory that will connect knowledge taught and instructional strategies given (Merrill, 1994, p. 112). Merrill elaborates knowledge components in CDT taxonomy which relates capability dimensions (remember, use and find) to content dimension (facts, concept and pro-cedures). To remember implies a performance requiring students to explore their memories to reproduce or identify several information item that has been known before. To use implies a performance requiring students to apply several abstraction concepts into specific case. To find implies a performance requiring students to obtain or find new abstraction. Facts is something that is related to name, data, events, name of place or symbols used to represent forms, part or occurrence such as water drop representing those related to liquid. Concepts are groups of objects, events or symbols with general characteristics and are identified by common name. Procedures are sequence of steps needed by learner to achieve their objectives, to solve certain problems, or to produce something.

Online instruction such as MOOC is less relevant if it is solely based on learning theories (Gagne et al., 1992, p. 27) which consist of contiguity, repetition, reinforcement, social culture principles of learning, negotiated learning, situated cognition and activity theory. To create an effective e-learning, there are four factors that should be taken into account namely interaction, relevance, benefit and usage (Downes, 2012, p. 47). Eren Brewer (Downes 2012, pp. 449-501) states several effective principles to share resources. They are online self-organizing social system (abbreviated as OSOSS), resourses transformation, stuctured OSOSS, online resources, resources for learning 
communities, and diversities of community member.

\section{METHOD}

This study employs qualitative approach by using content analysis. Subjects of this study are several platform of MOOC available in Indonesia. There has been at least 7 MOOC conducted by education institution and organization. They are Indonesia X, Kampiun, Universitas Terbuka, MOOC APTIKOM, MOOC UNAIR, eLOK UGM and Glacier UNY. This study reviews MOOC models used by IndonesiaX (https://www.indonesiax.co.id/dashboard) and MOOC of Sekolah Pintar (https:// sekolahpintar.com ). Purposive sampling is used because those platforms fulfil the criteria of MOOC which are massive (reliable), open (free for everyone), online (using internet), in the form of course with enrolment requirement, starting date, and final date of instruction and assessment. The course studied might be used by people to learn and work from home amidst covid-19 pandemic. Contents that are analysed has similar theme namely Marketing. Other MOOC could not be used as subject due to several factors. For instance, there are problems on registration in which user are sent email to complete the registration but they could not log in. Registration in Kampiun MOOC is relatively easy but it is expired and not reactivated. Focus of this study is to explore MOOC model by using effectiveness indicator (Gamage et al., 2015, pp. 704-705) and CDT taxonomy from (Merrill, 1994, p.112) and those MOOC are widely used during Covid-19 pandemic. The use of CDT taxonomy is better than Bloom taxonomy because it is more complete. Bloom sets instructional objectives only based on knowledge, comprehension, application, analysis, synthesis and evaluation dimensions. In addition to measure capabilities, CDT also take characteristics and contents factors into account (Oka \& Tastra, 2015, p. 90). Codes used for content analysis in this study are as shown in Table 1.

\section{FINDINGS AND DISCUSSION}

A course taken to be subject of study is entitled Effective Marketing in Digital Era. It states that there has been great changes in which all aspects of our life have been connected. This course elaborates that Marketing 4.0 turns to be new approach in marketing which based on costumer behaviour (Aware, Appeal, Ask, Act, and Advocate). There are 6 materials delivered by different instructors and each material contains $36 \mathrm{sub}$ material. It is assumed that it takes 1 hour/week per for each material to study. Each has test every week in the form of multiple choice test containing 10 question per material. All sub material is presented in the form of video embedded in Youtube (using unlisted setting) and subtitle material that can be downloaded by using txt or srt format.

The course that is studied is Marketing and Sales Strategy and Sales Magic presented by two different instructors. Marketing and Sales Strategy (H-M1) contains $9 \mathrm{sub}$ materials and Super Sales Magic has 4 material with 14 sub material. Different with IndonesiaX, Sekolah Pintar doesnt have test/ evaluation for all its material. There is only material presented in the form of video using server from MOOC provider (not embedded in Youtube).

Having completed courses in two platform, the writer tries to show the findings and analyse the substance objectively. The analysis of substance of MOOC is based on skill category and CDT taxonomy for content analysis (Downes, 2012, p. 499). There are two dimensions which are capability dimensions (remember, use, and 
Table 1

Codes of Contents Effectiveness

\begin{tabular}{|c|c|c|}
\hline Dimensions & Components & Codes \\
\hline Technology & Media and methods of delivery & $\mathrm{T} 1$ \\
\hline \multirow[t]{3}{*}{ Pedagogy } & Interaction between students and faculty/tutor/students & P1 \\
\hline & Learning speed & $\mathrm{P} 2$ \\
\hline & Methodology followed by lecturers' design/tutor & P3 \\
\hline \multirow[t]{3}{*}{ Motivation } & Relevance & M1 \\
\hline & Trust & M2 \\
\hline & Satisfaction & M3 \\
\hline \multirow[t]{4}{*}{ Benefit } & Interface design & U1 \\
\hline & Learning environment & $\mathrm{U} 2$ \\
\hline & Navigation & U3 \\
\hline & Feedback & $\mathrm{U} 4$ \\
\hline \multirow[t]{3}{*}{ Content/material } & Relevance & $\mathrm{C} 1$ \\
\hline & Updated & $\mathrm{C} 2$ \\
\hline & Rich collaborative information & $\mathrm{C} 3$ \\
\hline \multirow[t]{3}{*}{ Support for learner } & Psychological and social support for students & S1 \\
\hline & Administrative support & S2 \\
\hline & Procedure of students' complaint & S3 \\
\hline \multirow[t]{6}{*}{ Assessment } & Self-asessment & A1 \\
\hline & Collaborative assesment & A2 \\
\hline & Periodic and varied course evaluation & A3 \\
\hline & Periodic review on performance & A4 \\
\hline & Evalation on students' satisfaction & A5 \\
\hline & Routine review on students' achievement & A6 \\
\hline \multirow[t]{3}{*}{ Future guidelines } & Approved by industry & N1 \\
\hline & Straight to opportunities & $\mathrm{N} 2$ \\
\hline & Exposure to other network & N3 \\
\hline \multirow[t]{4}{*}{ Collaboration } & With other learner & $\mathrm{CO} 1$ \\
\hline & With instructor & $\mathrm{CO} 2$ \\
\hline & With faculty & $\mathrm{CO} 3$ \\
\hline & With industry & $\mathrm{CO} 4$ \\
\hline \multirow[t]{3}{*}{ Interactivity } & With peers & I1 \\
\hline & With content/material & $\mathrm{I} 2$ \\
\hline & With instructor & I3 \\
\hline
\end{tabular}

find) and content dimension (facts, concept, and procedure). In addition, analysis is also conducted by sing e-learning effectiveness category (Gamage et al., 2015, p. 704) which consists of: technology, pedagogy, motivation, usability, content/material, support for learner, assessment, future direction, collaboration and interactivity.
Based on CDT taxonomy, the findings presented in Table 2 and 3. Similarities between the two courses are that their materials are presented by knowledgeable practitioners with lengthy of working experience in international corporates in Indonesia. The material is firstly given by presenting introduction or preview and 
Table 2

Marketing Topic of MOOC at IndonesiaX based on CDT Taxonomy

\begin{tabular}{lcccc}
\hline \multirow{2}{*}{ Capabilities } & \multicolumn{4}{c}{ Content } \\
\cline { 2 - 5 } & Facts & Concepts & Procedures & Principles \\
\hline To Find & & $\mathrm{V}$ & - & - \\
To Apply & & $\mathrm{V}$ & $\mathrm{V}$ & $\mathrm{V}$ \\
To Remember & $\mathrm{V}$ & $\mathrm{V}$ & $\mathrm{V}$ & $\mathrm{V}$ \\
\hline
\end{tabular}

Table 3

Marketing Topic of MOOC at Sekolah Pintar based on CDT Taxonomy

\begin{tabular}{lcccc}
\hline \multirow{2}{*}{ Capabilities } & \multicolumn{4}{c}{ Content } \\
\cline { 2 - 5 } & Facts & Concepts & Procedures & Principles \\
\hline To Find & & - & - & - \\
To Apply & & V & V & V \\
To Remember & - & V & V & V \\
\hline
\end{tabular}

then deep elaboration of material is given. Marketing is attractive science in business world. In term of its interface system, they have several similarities such as that they are easy to access, to register and materials presented are attractive and applicative. In addition, they have question section for instructors and course progresses are given. They also have free and paid course. However, the two courses do not facilitate users to discover concept, procedures and principles.

Striking differences that are also strength and weaknesses of the two courses are that IndonesiaX has more structured material, fresh visual on their video and good evaluation. Problem items presented do not only measure Low Order thinking skill but also high order thinking skills. The materials are presented by 6 different presenters following similar standard of presentation. The use of sample cases is also more updated than that of sekolah pintar. Unfortunately, Sekolah Pintar does not have evaluation section. Thus, user could not measure their comprehension. Visually, the video is less attractive because presenters uses standing board and present the material orally. Therefore, its readability is not good.

MOOC has great potentials to sharpen skills and competence of user. It is due to that material given is in line with prevailing condition and problems in Indonesia. Covid-19 Pandemic gives massive impact to the people. Layoff occurs in many companies and institution. Schools are not allowed to conduct face to face instruction. In addition, offline courses and raining could not also be given during pandemic. Therefore, MOOC is a creative and proactive solution for enhancing skill and competence needed by people.

Online and Component Display Theory (CDT) designed in MOOC is highly effective so that it may be a future learning alternatives. MOOC provides various materials which is in line with condition of Indonesia. Most small-scale businesses have undergone decrease in their sales income forcing them to sell their assets. Therefore, there is a need for special strategy to assist them by implementing new business model and digital transformation. Courses of Marketing Strategy and Digital Marketing presented 
in MOOC and taken as subject of this study might be accessed freely by all people of Indonesia.

MOOC requires high motivation of independent learning. Laird in 1985 stated that independent learning theories is selfdirecting meaning that questions are selfdirected based on existing experience. It could not be dictated, has immediate application and more problem than content-cantered learning. It also requires active participation and collaboration as well as makes use of experience. In addition, planning and evaluation is conducted based on certain standard; learning by doing and only by listening to material presented (Mudjiman, 2011, pp. 17-18). Learning development on MOOC system requires serious preparation to make content attractive. For instance, existing technologies are able to attract user to fig more information in the form of video content. It is shown by massive number of online learning. It is also shown by data that since launched up to April 2018, user of IndonesiaX is 154.792 and 12.833 have already finished the course (https:// dailysocial.id/post/indonesiax-edtech-2018). The data shows that people needs MOOC as learning alternative.

The success of MOOC is not only determined by learning motivation but also quality and effectiveness of their program. Data analysis presented in Figure 1 show that there enormous number of strength and weaknesses of MOOC program. Firstly, material presentation in the form of video facilitates comprehension. Video presented by IndonesiaX (referring to T1, P1 and U1) has good color composition and lightning focus on tutor. In addition, text presented on video is easy to read because white color text is presented using dark green background. It creates classic impression when teacher uses chalk on wood board. Animation presented is also facilitating students' understanding. Secondly, discussion forum is beneficial for user (referring to I2 Figure 2 ). It is not only used for communication and share experience between students and instructors but also to give respond to other students (Mudjiman, 2011, p. 15). Thirdly, Table 2 (referring to U2 and U3) presents learning progress that might be accessed by students and it supports self-directing concept (Mudjiman, 2011, pp. 14-15). Fourthly, involvement of lecturers and company practitioners to develop MOOC gives positive result in terms of material presentation and it attracts user to select the courses (Figure 1 on N1 and CO4).

However, MOOC has several weaknesses. Firstly, there is no collaboration among students and instructors which makes it instructor-centered. Secondly, there is no evaluation for students' satisfaction as user (Figure 2 on A5). It is important to evaluate and develop the MOOC. Sekolah Pintar doesn't provide self-assessment. Therefore, it is hard to find out comprehension level of user and it could not be used as standard of success of MOOC provider. There is no collaborative assessment because the MOOC doesn't provide collaborative media. Thirdly, standard of material presentation should be taken into account. It is shown by material presented by Sekolahpintar. com and IndonesiaX. In IndonesiaX, although materials are presented by 6 instructors but the standard are similar. On Sekolahpintar.com, especially material presented by second up to fourth instructor (Is2-Is4), they have different standard and first instructor of Sekolahpintar.com shows significant difference. First instructor of Sekolahpintar.com (Is1) is better-prepared than that of second up to fourth instructor of Sekolahpintar.com. They use face to face seminar documentation and the video was edited into subtheme and uploaded in the form of material collection. 


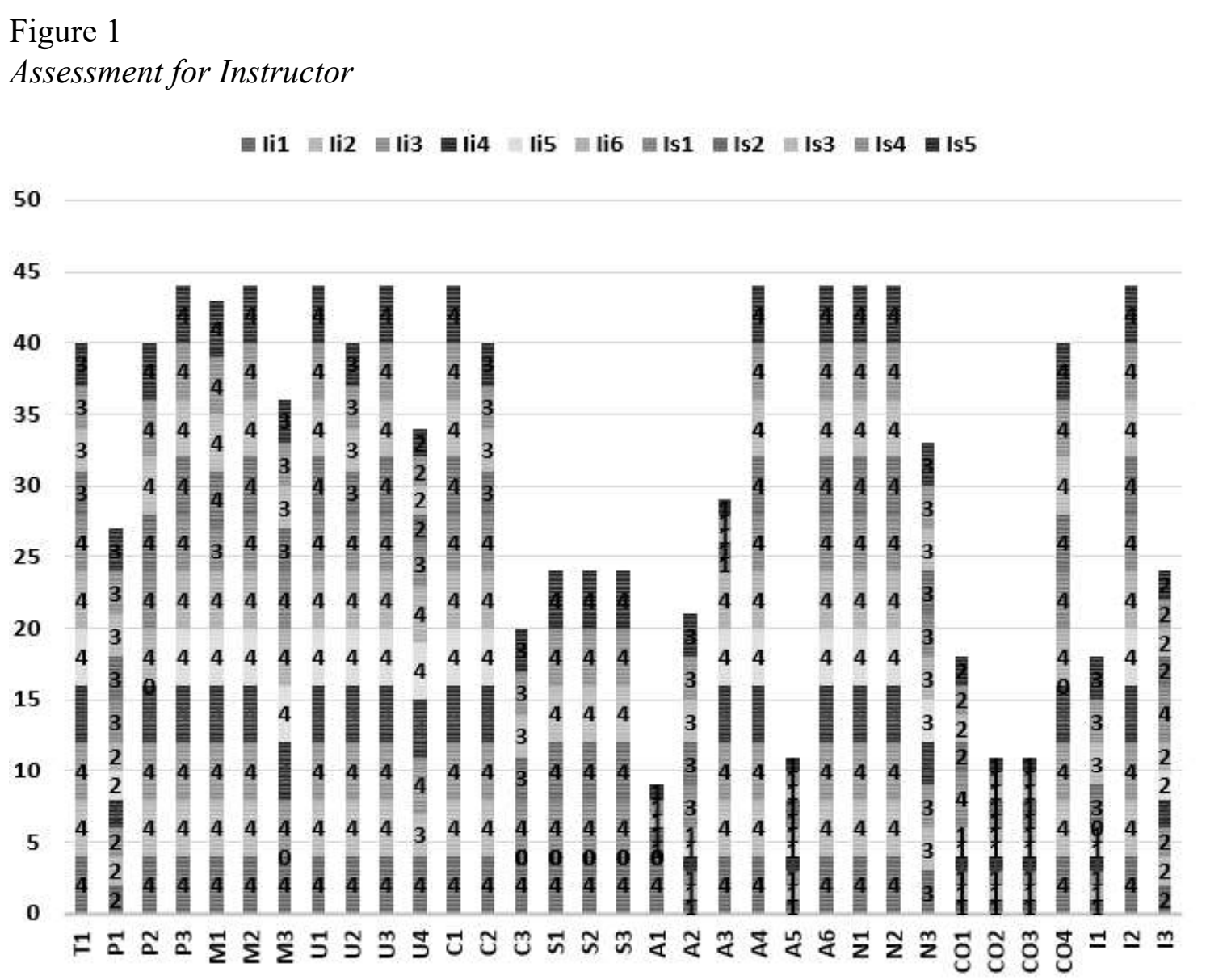

Figure 2

Assesment Based on Effetiveness Dimension

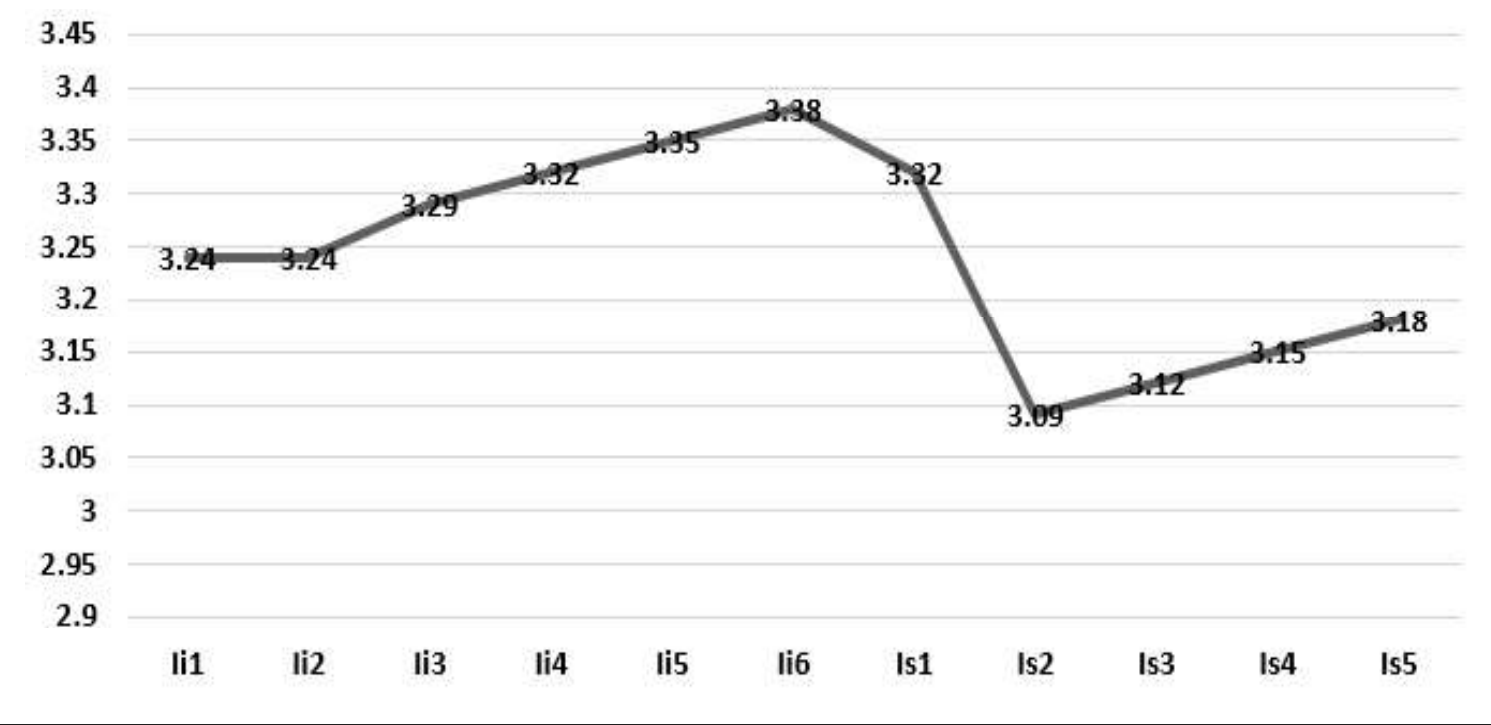


Though most user of MOOC especially those accessing Marketing material are fresh entrepreneur or even students, orientation of user comprehension should be taken into serious account. For existing MOOC, mode of presentation is more important than its evaluation. Therefore, based on experience pyramid of Dale, it is possible that user memory is only $30 \%$. In addition, the memory level will increase up to $50 \%$ if users are involved in discussion and obtain direct feedback from their peers. If users are involved in collaborative works and are given chance to present their work, then their memory level will reach $70 \%$ (Davis \& Summers, 2015, p. 2).

Based on the analysis presented above, there are several important points that should be taken into account. They are determining learning objectives based on CDT taxonomy, fulfilling all theoretical dimension (10 dimensions provided by Gamage) in producing effective MOOC, arising motivation on the part of students to create independent learning awareness, creating collaborative learning environment, providing content needed by user, and giving chance for user to take part in peer discussion and present the result of discussion.

\section{CONCLUSION}

To develop MOOC, method of delivery should match the user of MOOC. Based on the results of the MOOC analysis in Indonesia, the comparison between IndonesiaX and SekolahPintar shows that both of them are presented by practitioners who have long been involved in large Indonesian companies, the interface system has several similarities, including menus that are easy to access, easy registration, material interesting and applicable, there is a question column on the instructor, can see the progress of the course, there are free and paid courses. The main difference between the two MOOCs is that IndonesiaX has a more structured presentation of content, videos with fresh visuals and has excellent evaluation. The questions presented also do not only measure low order thinking skills, but also present high order thinking skills questions. The MOOC also has great potential to support the freedom of learning of Indonesians. During a pandemic, a MOOC is needed which provides learning related to life skills, for example marketing skills or other skills that can make the community, especially for small bussiness, survive and rise again. MOOC needs to be developed based on the CDT taxonomy and pay attention to 10 effective MOOC dimensions are technology, pedagogic, motivation, usability, content/ material, support for learners, assessment, future directions, collaboration, interactivity. Based on the results of the analysis, it appears that IndonesiaX is more effective when compared to SekolahPintar.com. Though this study could not identify type of development used by MOOC such as IndonesiaX and Sekolahpintar.com, the writer suggests that MOOC developer use proper MOOC development model such as RAPID, P3, Udemy or Coursesites (Oka \& Tastra, 2015, pp. 55-74).

\section{REFERENCES}

Aji, R. H. S. (2020). Dampak Covid-19 pada pendidikan di Indonesia: Sekolah, keterampilan, dan proses pembelajaran. SALAM: Jurnal Sosial \& Budaya Syar-I, 7(5), 395-402. https://doi. org/10.15408/sjsbs.v7i5.15314.

Chauhan, J. \& Goeal,A. (2017). An overview of MOOC in India. International Journal of Computer Trends and Technology, 39(2), 111-120.

CNNIndonesia.com. (2020). Pekerja dirumahkan dan kena phk akibat corona capai 3,05 juta. 1-9. https:// www.cnnindonesia.com. 
Conijn, R., Van den Beemt, A., \& Cuijpers, P. (2018). Predicting student performance in a blended MOOC. Journal of Computer Assisted Learning, 34(5), 615-628.

Davis, B., \& Summers, M. (2015).. Applying Dale's Cone of Experience to increase learning and retention: A study of student learning in a foundational leadership course. QScience Proceedings, Engineering Leaders Conference 2014 on Engineering Education, 2015(4), 6. https://doi.org/10.5339/qproc.2015. elc2014.6.

Downes, S. (2012). Connectivism and Connective Knowledge: Essays on meaning and learning networks. National Research Council Canada.

Firman, F., \& Rahayu, S. (2020). Pembelajaran online di tengah pandemi Covid-19. Indonesian Journal of Educational Science (IJES), 2(2), 81-89. https://doi. org/10.31605/ijes.v2i2.659.

Gagne, R. M., Briggs, L. J., \& Wager, W. W. (1992). Principles of instructional design ( $4^{\text {th }}$ ed.). Harcourt Brace College Publishers.

Gamage, D., Fernando, S., \& Perera. (2015). Quality of MOOCs: A review of literature on effectiveness and quality aspects. $8^{\text {th }}$ International Conference on Ubi-Media Computing (UMEDIA), 2015, 224-229. doi: 10.1109/ UMEDIA.2015.7297459.

Gamage, D., Perera, I., \& Fernando, S. (2015). Effectiveness of eLearning through MOOC Grounded theory approach.pdf. 693-711. https://doi. org/10.1109/MERCon.2015.7112369

Kossek, E. E., Thompson, R. J., \& Lautsch, B. A. (2015). Balanced workplace flexibility: Avoiding the traps.
California Management Review, 57(4), 5-25.

Kusmawan, U. (2016). Kesiapan belajar mandiri guru sekolah dasar: Studi kasus pada Program Studi PGSD pada FKIP Universitas Terbuka. Jurnal Pendidikan dan Kebudayaan, 1(3), 279-293.

Merrill, M. D. (1994). The descriptive component display theory (pp. 111157). Dalam G. Kearsley, Explorations in learning \& instruction: The theory into practice database (pp. 111-157). Educational Technology Publications.

Mudjiman, H. (2011). Belajar mandiri (3 ${ }^{\text {rd }}$ ed.). LPP, UNS, dan UNS Press.

Oka, G. P. A., \& Tastra, I. D. K. (2015). Massive open online course (Web pembelajaran masa depan). Teknosain.

Onah, D. F., Sinclair, J. E., \& Boyatt, R. (2014, November). Exploring the use of MOOC discussion forums. Dalam Proceedings of London International Conference on Education (pp. 1-4). The University of Warwick, London.

Purnomo, W. (2016, Maret). Penerapan massive open online course (MOOC) berbasis moodle sebagai learning management system (LMS). Makalah dipresentasikan pada Simposium Nasional Pengembang Teknologi Pembelajaran. Jakarta.

Reich, J. (2015). Rebooting MOOC research. Science, 347(6217), 34-35. doi: 10.11-26/science.1261627.

Tempo. (2020). Dampak corona, 3,05 juta orang terkena PHK Hingga Juni. https://bisnis.tempo.co.

van der Lippe, T., \& Lippényi, Z. (2020). Co-workers working from home and individual and team performance. New Technology, Work and Employment, 35(1), 60-79. 